\title{
CO2-BRINE-ROCK INTERACTIONS: THE EFFECT OF IMPURITIES ON GRAIN SIZE DISTRIBUTION AND
}

\section{RESERVOIR PERMEABILITY}

\begin{abstract}
The Bunter Sandstone formation in the UK Southern North Sea has been identified as having the potential to store large volumes of $\mathrm{CO}_{2}$. Prior to injection, $\mathrm{CO}_{2}$ is captured with certain amounts of impurities, usually less than $5 \%$ vol. The dissolution of these impurities in formation water can cause chemical reactions between $\mathrm{CO}_{2}$, brine, and rock, which can affect the reservoir quality by altering properties such as permeability. In this study, we explored the effect of $\mathrm{CO}_{2}$ and impurities $\left(\mathrm{NO}_{2}, \mathrm{SO}_{2}, \mathrm{H}_{2} \mathrm{~S}\right)$ on reservoir permeability by measuring changes in grain size distributions after a prolonged period of 9 months, simulating in situ experimental conditions. It was found that the effects of pure $\mathrm{CO}_{2}$ and $\mathrm{CO}_{2}-\mathrm{H}_{2} \mathrm{~S}$ are relatively small, i.e., $\mathrm{CO}_{2}$ increased permeability by $5.5 \%$ and $\mathrm{CO}_{2}-\mathrm{H}_{2} \mathrm{~S}$ decreased it by $5.5 \%$. Also, $\mathrm{CO}_{2}-\mathrm{SO}_{2}$ slightly decreased permeability by $6.25 \%$, while $\mathrm{CO}_{2}-\mathrm{NO}_{2}$ showed the most pronounced effect, reducing permeability by $41.6 \%$. The decrease in permeability showed a correlation with decreasing $\mathrm{pH}$ of the formation water and this equally correlates with a decrease in geometric mean of the grain diameter. The findings from this study are aimed to be used in future modelling studies on reservoir performance during injection and storage, which also should account for the shifts in boundaries in the $\mathrm{CO}_{2}$ phase diagram, altering the reservoir properties and affecting the cost of storage.
\end{abstract}

\section{Abbreviations}

BSE Backscatter Electron 


$\begin{array}{ll}\text { ESEM } & \text { Environmental Scanning Electron Microscope } \\ \text { GHGs } & \text { Greenhouse Gases } \\ \text { PTFE } & \text { Polytetrafluoroethylene } \\ \text { QXRD } & \text { Quantitative X-ray Diffraction } \\ \text { SDD } & \text { Silicon Drift X-ray Detector } \\ \text { S-CO } & \mathrm{CO}_{2} \text { rock sample } \\ \text { S-CO }-\mathrm{NO}_{2} & \mathrm{CO}_{2}-\mathrm{NO}_{2} \text { rock sample } \\ \text { S-CO }-\mathrm{SO}_{2} & \mathrm{CO}_{2}-\mathrm{SO}_{2} \text { rock sample } \\ \text { S-CO }-\mathrm{H}_{2} \mathrm{~S} & \mathrm{CO}_{2}-\mathrm{H}_{2} \mathrm{~S} \text { rock sample } \\ \text { S-NR } & \mathrm{Non}_{-} \text {reacted rock sample } \\ \text { UKSNS } & \text { UK Southern North Sea } \\ \text { XRD } & \text { X-ray Diffraction }\end{array}$

\section{Introduction}

Since the start of the industrial revolution, there have been increases in the atmospheric concentration of $\mathrm{CO}_{2}$ and other greenhouse gases (GHGs) (IPCC, 2005), which in turn resulted in a rise of the global average surface temperature, and consequently climate change (IPCC, 2005; Riebeek, 2011). Between 1906 and 2017, the global average surface temperature rose 0.6-1.05 ${ }^{\circ} \mathrm{C}$ (NOAA National Centers for Environmental Information, 2017; Riebeek, 2011), and the rate of increase has almost doubled in the last 50 years (Riebeek, 2011). The average temperature is certain to rise further unless climate change mitigation strategies are implemented. Carbon capture and storage (CCS) is a key technology aimed at reducing $\mathrm{CO}_{2}$ emission to the atmosphere. $\mathrm{CCS}$ involves capturing $\mathrm{CO}_{2}$ from large point sources and storing it underground in geologic formations such as saline aquifers, depleted oil and gas reservoirs, unmineable coal seams and basalt formations (Aminu et al., 2017; IPCC, 2005). 
The storage reservoirs are formed of aggregated rock minerals, and mineralogical properties can change upon variation in reservoir conditions, such as acidity of formation waters, during injection of $\mathrm{CO}_{2}$. The changes in mineralogy can often be complex, which could lead to the formation of new minerals and/or obliteration of pre-existing minerals. These changes alter individual grain contacts to either increase or reduce their ability to transmit and store fluids. Thus, one of the greatest variability factors which determines the efficiency of storage is influenced by the host reservoir properties such as porosity, permeability, pressure and temperature of formation and mineralogical composition (Bond et al., 2013; Bouquet et al., 2013; Kaldi, JG Gibson-Poole, CM Payenberg, 2009; Verdon, 2012).

Several experimental and numerical studies on $\mathrm{CO}_{2}$ storage in geological media have reported that a significant amount of alteration of rock properties could occur following injection of $\mathrm{CO}_{2}$ in the reservoir due to the decrease of pH of formation waters (Dance, 2013; Hussain et al., 2016; Jenkins et al., 2012; Li and Jiang, 2014; Perrin and Benson, 2010; Ranjith et al., 2013; Torp and Gale, 2004; Wollenweber et al., 2009). Although these alterations are slow under laboratory test conditions, they could be significant and more complex over the storage time frame (Liu et al., 2012).

More recently, some studies have investigated the influence of $\mathrm{CO}_{2}$ and associated impurities on the reservoir formation through batch experiments (Jafari Raad and Hassanzadeh, 2016; Pearce et al., 2016b, 2016a, 2015b, 2015a; Wang et al., 2015; Z. Wang et al., 2016) and geochemical modelling (Lei et al., 2016; Pearce et al., 2016a; Waldmann et al., 2016; Waldmann and Rütters, 2016; Wolf et al., 2016) for both reservoir and caprock core samples obtained from different locations around the world. It was reported that the presence of impurities in the injected $\mathrm{CO}_{2}$ stream can potentially affect the reservoir storage capacity (Talman, 2015), fluids miscibility in oil and gas reservoirs (Coelho et al., 2015), solubility 
trapping (Li and Jiang, 2014; Ziabakhsh-Ganji and Kooi, 2014), and corrosion of well casings, which can result in environmental concerns in the case of leakage from injection facilities (Ziabakhsh-Ganji and Kooi, 2014), and increased storage cost (Wang et al., 2015).

It was reported that the dissolution of quartz increased after exposure to $\mathrm{CO}_{2}$ and $\mathrm{SO}_{2}$ in highpressure reactors for 45 days using samples from a potential saline aquifer storage formation in western Canada (Z. Wang et al., 2016). Results from the same study highlighted the importance of assessing the rate of quartz dissolution to determine suitable operation conditions for $\mathrm{CO}_{2}$ injection and storage. Pearce et al. (Pearce et al., 2016b) studied mineralogical controls on porosity and brine chemistry during $\mathrm{O}_{2}-\mathrm{SO}_{2}-\mathrm{CO}_{2}$ reaction in $\mathrm{CO}_{2}$ storage reservoirs using samples obtained from a potential reservoir in Queensland, Australia. They reported that there was no change in the mineralogically clean quartzose core samples with originally high porosities after 3 days of exposure to fluids. However, it was noted that the movement of minerals, such as kaolin, in the core samples can potentially reduce the permeability by blocking pore throats.

Although several studies have investigated $\mathrm{CO}_{2}$-water-rock interactions in reservoir conditions to ascertain mineral reactions and their effects on physical reservoir quality through the alteration of porosity and permeability, the variation of grain size distribution and corresponding impact on permeability upon exposure to impurities contained in $\mathrm{CO}_{2}$ streams in reservoir conditions are yet to be explored (Aminu et al., 2017). It is important to note that the reservoir rock permeability is a function of grain size distribution (Krumbein and Monk, 1943; Masch and Denny, 1966), and this can be affected by the $\mathrm{pH}$ of formation water based on the composition of injected fluids (Aminu et al., 2017; Liu et al., 2012; Shukla et al., 2010). Additionally, the majority of work available in the open literature has been based on relatively short-term tests, between 12 days and 6 months (Bolourinejad and Herber, 2014; Soong et al., 
2016; K. Wang et al., 2016; Z. Wang et al., 2016). Also, it should be noted that within the previous studies, the effects of impurities on reservoir rock were only considered for exposure periods of 45 days $\left(\mathrm{CO}_{2}-\mathrm{SO}_{2}\right.$ test $)$ and 30 days $\left(\mathrm{CO}_{2}-\mathrm{H}_{2} \mathrm{~S}\right.$ test $)$, while all other studies considered the effect of only $\mathrm{CO}_{2}$. Also, due to the inherent heterogeneous assemblages of depositional facies and sub-facies in the reservoir, it is important to address morphological changes through extended experimental tests under more realistic conditions.

Therefore, the aim of this study is to assess the effect of $\mathrm{CO}_{2}$ and impurities $\left(\mathrm{NO}_{2}, \mathrm{SO}_{2}\right.$, and $\mathrm{H}_{2} \mathrm{~S}$ ) on the reservoir grain size parameters and to determine their impacts on physical reservoir quality using permeability variations as indications. Rock samples from the Bunter Sandstone formation (BSF) in the UK Southern North Sea were exposed to $\mathrm{CO}_{2}$ and impurities for a prolonged period, and the resulting morphological changes were explored. The results from this study are aimed to be used in future studies for characterisation and modelling of reservoir performance under different compositions of injected fluids.

\section{Geological background}

The BSF in the UK Southern North Sea (UKSNS) has been identified as a target reservoir due to its significant potential to store large amounts of $\mathrm{CO}_{2}\left(3.8-7.8 \mathrm{Gt}\right.$ of $\mathrm{CO}_{2}$ could be stored using a multi-well injection strategy for a period of 30 years depending on maximum safe

pressure increase) (Aminu et al., 2017; Heinemann et al., 2012). Figure 1 shows the distribution of the formation and its onshore stratigraphic equivalent, and a generalised stratigraphy of the offshore UKSNS. The formation has both the required reservoir properties for $\mathrm{CO}_{2}$ storage and a suitable caprock which acts as a seal to prevent $\mathrm{CO}_{2}$ leakage (Heinemann et al., 2012; Holloway et al., 2006; Noy et al., 2012; Williams et al., 2014, 2013b). A study of the BSF top seals has indicated that the presence of the over eight natural gas fields where the 
formation occurs demonstrates the capability of the formation to effectively seal significant gas volumes over geologic timescales (Williams and Holloway, 2012). Although the formation of domal structures within the BSF have subjected the overlying top seals to extensional stresses, but it does not appear to have affected the ability of the faults to seal $\mathrm{CO}_{2}$ (Noy et al., 2012; Williams et al., 2014, 2013b, 2013a; Williams and Holloway, 2012). However, modelling for large-scale $\mathrm{CO}_{2}$ injection into the formation indicated that more detailed evaluations are required along the reservoir, specifically around the injection point and at regional scale to conclusively determine the structural integrity as well as $\mathrm{CO}_{2}$ storage capacity (Noy et al., 2012).

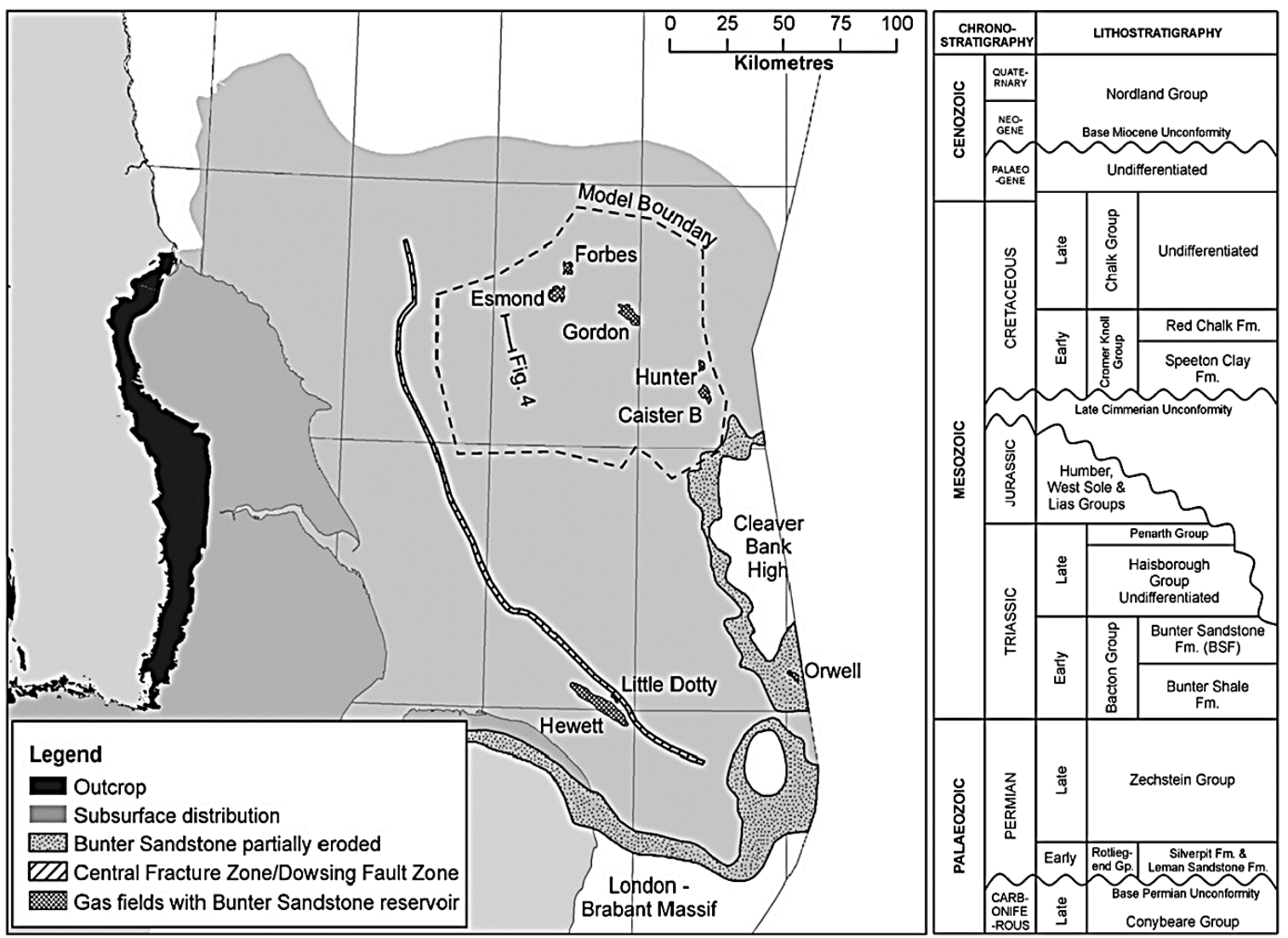

Figure 1: Distribution of the Bunter Sandstone formation (offshore) and Sherwood Sandstone Group (onshore) in the UK Southern North Sea (UKSNS) and eastern 


\section{England (Noy et al., 2012) and generalised stratigraphy of the offshore UKSNS}

(Williams et al., 2014).

The BSF was deposited between 230 and 260 million years ago during the late Permian and Triassic periods. It comprises pebbly sandstones and sandstones intercalated with low amounts of conglomerates, mudstones and siltstones. The BSF reservoir is typically $200 \mathrm{~m}$ or more thick, with fair to good porosity and permeability, and it is found at depths between 1000 3000 m (Noy et al., 2012).

There are eight gas fields in the UKSNS where the BSF occurs. The development of salt pillows and domes within the underlying Zechstein Group led to the formation of periclinal folds within the formation (Underhill, 2009) and some of these periclines are gas-bearing (Ritchie and Pratsides, 1993) while others are not (Noy et al., 2012).

Bifani (Bifani, 1986a) studied the depositional environment of the Gordon, Forbes and Esmond gas fields complex which shows an arid to semi-arid fluvial depositional environment consisting of alluvial fans dissected by braided fluvial channels. Ritchie and Pratsides (Ritchie and Pratsides, 1993) reported that around the Caister B gas field, sediment is sourced from the west-southwest, and is thought to drain into a playa lake to the north and northeast of the field through a series of low-sinuosity channels, which transect a low-relief alluvial braid plain.

The porosity and permeability for the BSF reservoirs were investigated by Cooke-Yarborough and Smith (Cooke-Yarborough and Smith, 2003), Ritchie and Pratsides (Ritchie and Pratsides, 1993) and Bifani (Bifani, 1986a, 1986b), and typical values for fields are: $21 \%$ and $500 \mathrm{mD}$ (Hewett); $21 \%$ and $350 \mathrm{mD}$ (Little Dotty); 23-24\% and $87 \mathrm{mD}$ (Esmond); $21 \%$ and $100 \mathrm{mD}$ (Caister B); 15-25\% (Forbes); and 14-21\% (Gordon). Ketter (Ketter, 1991) reported the occurrence of halite and anhydrite cements within the BSF, with quantities varying within 
respective fields. The halite cementation which fills rock pores shows that it can be a barrier to permeability below the gas-water contact in the formation of the Caister B field (Ritchie and Pratsides, 1993), while in the Gordon, Forbes and Esmond fields, a patchy distribution of halite cementation, which obliterates porosity, is prominent within coarser-grained sandstones (Bifani, 1986a, 1986b).

In areas of the UKSNS where hydrocarbons are not found, highly saline brines fill up open pore spaces of the rock formations. This makes the BSF hydrostatically pressured with variable amounts of brine of variable salinity and density. Brine salinities and brine densities were investigated by Ritchie and Pratsides (Ritchie and Pratsides, 1993) and Warren and Smalley (Warren and Smalley, 1994). Typical values for fields are: $294000 \mathrm{ppm}$ and $1.211 \mathrm{~g} \mathrm{~cm}^{-3}$ (Esmond); $303000 \mathrm{ppm}$ and $1.220 \mathrm{~g} \mathrm{~cm}^{-3}$ (Forbes); $180000 \mathrm{ppm}$ and $1.119 \mathrm{~g} \mathrm{~cm}^{-3}$ (Orwell); and $250000 \mathrm{ppm}$ and $1.174 \mathrm{~g} \mathrm{~cm}^{-3}$ (Caister B). Using a fluid property mixture simulator (TOUGH2), Pruess (Pruess, 2005) calculated in situ temperature and pressure for the BSF as $42^{\circ} \mathrm{C}$ and $9.39 \mathrm{MPa}$, respectively, at $884 \mathrm{~m}$.

The BSF is structurally compartmentalised (Noy et al., 2012) and the nature of these compartments in a reservoir is relevant in determining $\mathrm{CO}_{2}$ storage capacity in saline aquifers. The effective pore volume of each compartment, compartment boundary permeability and compressibility of rock and fluids are key parameters which control the amount of $\mathrm{CO}_{2}$ which can be injected into a reservoir before pore fluid pressure is reached, which is a limiting factor (Noy et al., 2012). Although little published literature exists on the extent of compartmentalisation within the formation, Cooke-Yarborough and Smith (CookeYarborough and Smith, 2003) reported a pressure communication between the Little Dotty field and the Hewett gas fields even though these fields are approximately $5 \mathrm{~km}$ apart (Noy et al., 2012). 


\subsection{Experimental procedure}

Rock samples from the BSF were used for experiments in this study. The samples were obtained from the UKSNS hydrocarbon industry well 43/12-1 at approximately $1392 \mathrm{~m}$. It should be noted here that although more realistic porosity and permeability values can be measured using core samples, crushed samples were used in this study because of unavailability of core samples from the BSF. Crushed samples were reacted in bespoke titanium pressure vessels, Figure 2. Each pressure vessel $(430 \mathrm{~mL})$ had a gas inlet and a fluid outlet, where the gas inlet was used to supply $\mathrm{CO}_{2}$ into the vessel through a pair of ISCO 500D syringe pumps (USA) running in 'constant pressure' mode (Gunter et al., 1993; Weibel et al., 2014). Four set of batch experiments were conducted for a period of 9 months. The experiments are designated as $\mathrm{CO}_{2}$-brine-rock, $\mathrm{CO}_{2}-\mathrm{NO}_{2}$-brine-rock, $\mathrm{CO}_{2}-\mathrm{SO}_{2}$-brine-rock, and $\mathrm{CO}_{2}-\mathrm{H}_{2} \mathrm{~S}$ brine-rock, considering the impurities added to $\mathrm{CO}_{2}$ reacting with the brine rock.

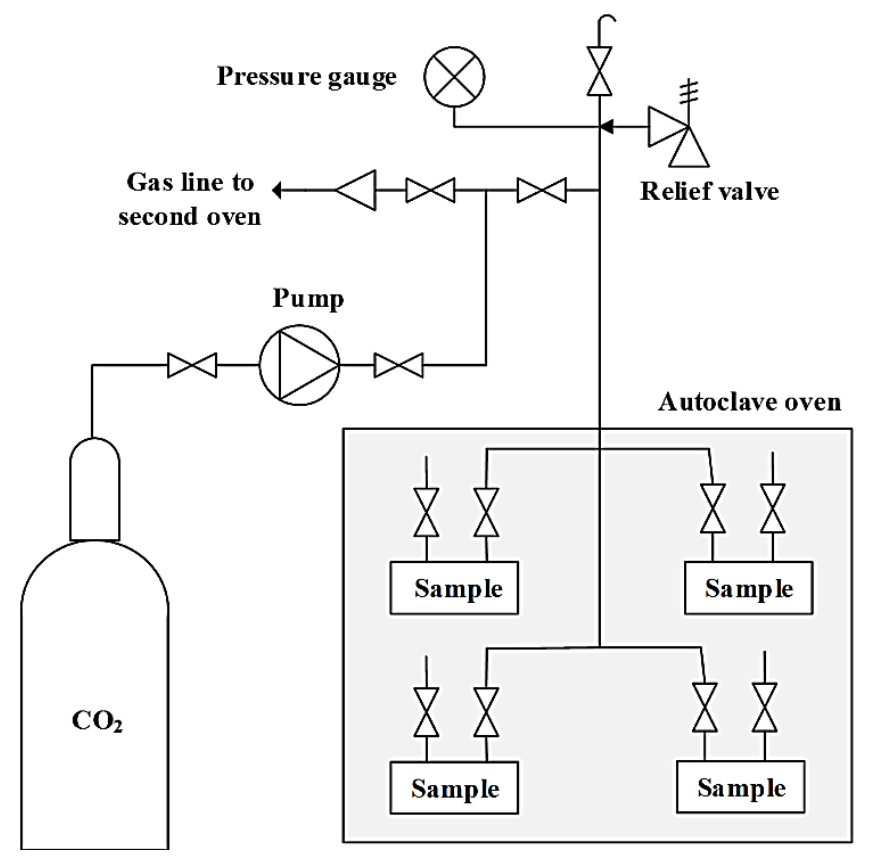

Figure 2: Schematic diagram of experimental set-up. 
A magnetic stirrer was used to provide sufficient mixing between gases, pore water and samples in the vessel. The PTFE-covered stirrer was placed at the base of each experiment so as to have direct contact with synthetic water and rock sample. The sample was agitated every four hours for two minutes using a stirrer bar. The stirring speed was relatively low in order to avoid degrading the samples. A pressure of 140 bar, which was close to the in situ pressure of the origin formation of the samples, was used in the experiments. An elevated temperature of $70{ }^{\circ} \mathrm{C}$, which was higher than the in situ temperature, was used to accelerate chemical reactions, i.e., to simulate longer exposure to the $\mathrm{CO}_{2} /$ impurities-containing fluid. The $0.5 \mathrm{M} \mathrm{NaCl}$ used in the experiments was prepared with $18 \mathrm{M} \Omega$ demineralised water using analytical grade reagents. $300 \mathrm{~mL}$ of solutions was added to each vessel with $15 \mathrm{~g}$ of crushed rock with size range $125-500 \mu \mathrm{m}$. Since a $\mathrm{CO}_{2}$ concentration of $95 \%$ vol and above is typically required for storage applications, $\mathrm{CO}_{2}$ with $5 \%$ vol impurities was used for each test, and the samples with the corresponding content of the impurity in $\mathrm{CO}_{2}$ are tabulated in Table 1. The $\mathrm{pH}$ of the fluid was measured at the beginning and at the end of the tests, i.e., after 9 months. For each set of the experiment, $1 \mathrm{~mL}$ of the reacted fluid was taken for $\mathrm{pH}$ measurements. The procedure consisted of degassing the aqueous fluid straight into a polythene syringe, and immediate $\mathrm{pH}$ measurement at room temperature after sampling and degassing, using an Orion VERSA STAR $\mathrm{pH}$ meter. It should be noted that since the dissolved $\mathrm{CO}_{2}$ is degassed to reach equilibrium with the atmosphere, the measured $\mathrm{pH}$ is higher than the in situ values. However, it has been shown that the degassing effects are considerable only after several hours (Bateman et al., 2015), and it is expected that the discrepancy between measured and in situ $\mathrm{pH}$ values is negligible in this work.

Table 1: Test designation and impurity content (\% vol.). 


\begin{tabular}{lcccc}
\hline Test & $\mathrm{CO}_{2}$ & $\mathrm{NO}_{2}$ & $\mathrm{SO}_{2}$ & $\mathbf{H} \mathbf{S}$ \\
\hline $\mathrm{S}-\mathrm{NR}$ & - & - & - & - \\
\hline $\mathrm{S}-\mathrm{CO}_{2}$ & 100 & - & - & - \\
\hline $\mathrm{S}-\mathrm{CO}_{2}-\mathrm{NO}_{2}$ & 95 & 5 & - & - \\
\hline $\mathrm{S}-\mathrm{CO}_{2}-\mathrm{SO}_{2}$ & 95 & - & 5 & - \\
\hline $\mathrm{S}-\mathrm{CO}_{2}-\mathrm{H}_{2} \mathrm{~S}$ & 95 & - & - & 5 \\
\hline
\end{tabular}

Upon completion of the tests, samples were collected from the pressure vessel, placed onto a small Buchner funnel, and washed with deionised water to remove saline fluid. The samples were then dried under partial vacuum before further analysis.

\subsection{Material characterisation}

\subsubsection{X-ray diffraction (XRD) analysis}

XRD analysis was conducted using a PANalytical X'Pert Pro series diffractometer equipped with a cobalt-target tube and operated at $45 \mathrm{kV}$ and $40 \mathrm{~mA}$. Samples were scanned from 4.5$85^{\circ} 2 \theta$ at $2.06^{\circ} 2 \theta /$ minute. Diffraction data were initially analysed using PANalytical X'Pert Highscore Plus version 4.1e software. Quantitative mineralogical data were accomplished using a least squares fitting process applying the Rietveld refinement technique (Rietveld, 1969; Taylor, 1991). For the whole-rock XRD analysis, the samples were ground in a pestle and mortar and then micronised to a fine powder $(<10 \mu \mathrm{m})$ using acetone. A $10 \%$ portion of corundum standard was added to each sample prior to micronising to detect and quantify crystal and amorphous phases present in the samples. The samples were then back-loaded into standard sample holders for analysis. 


\subsubsection{Fluid sample analysis}

The samples were first filtered using a $0.2 \mu \mathrm{m}$ Anotop® nylon syringe filter, and then placed into a polystyrene tube. Inductively-coupled-plasma mass spectrometry (ICP-MS) and ion chromatography (IC) techniques were used to analyse the reacted fluid samples with respect to major and trace cations and anions.

\subsubsection{ESEM analysis}

Image acquisition was conducted using a FEI XL30 environmental scanning electron microscope (ESEM) equipped with Oxford Instruments AZTec Energy Dispersive X-ray Spectroscopy software with a $50 \mathrm{~mm}^{2}$ Peltier-cooled silicon drift X-ray detector (SDD). Samples were prepared as grain mounts without conductive coatings and under variable pressure conditions, using water as the SEM chamber atmosphere at pressure of 0.8 Torr. Images were obtained using the backscatter electron (BSE) imaging technique.

\subsection{Image analysis}

The estimation of permeability can be done by: (a) field pumping or injection test; (b) permeameter; or (c) available empirical relationships (Shepherd, 1989). In this study, we adopted the latter approach, since it provides an effective method for approximation of variations in grain size and grain sorting after weathering of rock minerals by $\mathrm{CO}_{2}$-charged brine. In general, the field pumping or injection test can be time consuming and expensive (Shepherd, 1989). On the other hand, the laboratory measurements of fluid flows through whole rock cores using a permeameter do not allow for the provision of loose grain samples and a more exposed grain surface area per unit volume for effective analysis. Although the best approach to quantify reservoir-scale permeability is measuring the permeability of intact whole 
rock cores, it has been shown that empirical correlations can also be used as a valid alternative approach to estimate permeability of reservoir sandstones from unconsolidated rock samples (Coskun and Wardlaw, 1993). Namely, Coskun and Wardlaw (Coskun and Wardlaw, 1993) compared the measured permeability of sandstone rock samples with estimated values from empirical correlations. They reported that the coefficient of determination varied between 0.90 0.94, which indicates the high accuracy of empirical correlations for estimation of the permeability of rock samples.

Mostaghimi et al. (Mostaghimi et al., 2013) and Blunt et al. (Blunt et al., 2013) used image analysis to cover a range of applications such as understanding the behaviour of supercritical $\mathrm{CO}_{2}$ in aquifers for effective and long-term containment. This revealed that, like other physical properties of porous materials, permeability is a function of a material's complex microstructure. Although many researchers in the past have attempted to relate permeability to other computed parameters such as specific surface area and porosity (Bear, 1988), there is still no explicit function to accurately correlate permeability, which is crucial to model flow through porous media (Mostaghimi et al., 2013). Alternatively, the Krumbein and Monk method (Krumbein and Monk, 1943), later adopted by Beard and Weyl (Beard and Weyl, 1973), is used in this study for more accurate prediction of permeability. In this method, 2D-highresolution images of rock are obtained from the 3D representations of the samples (Thovert et al., 1993). This is achieved using the object-based method, which allows measuring grain shape and size (Øren et al., 1998) as well as statistical analyses of the objects deposited in the 2D images (Adler et al., 1990; Okabe and Blunt, 2004; Roberts, 1997) as opposed to 3D stack. This method has been commonly used by researchers. For example, Coskun and Wardlaw (Coskun and Wardlaw, 1993) employed this approach to estimate the rock permeability in a North American oil reservoir using 2D images of rock samples. Figure 3 provides an example 
of the image analysis process used in this work to estimate the permeability from $2 \mathrm{D}$ images of rock samples.

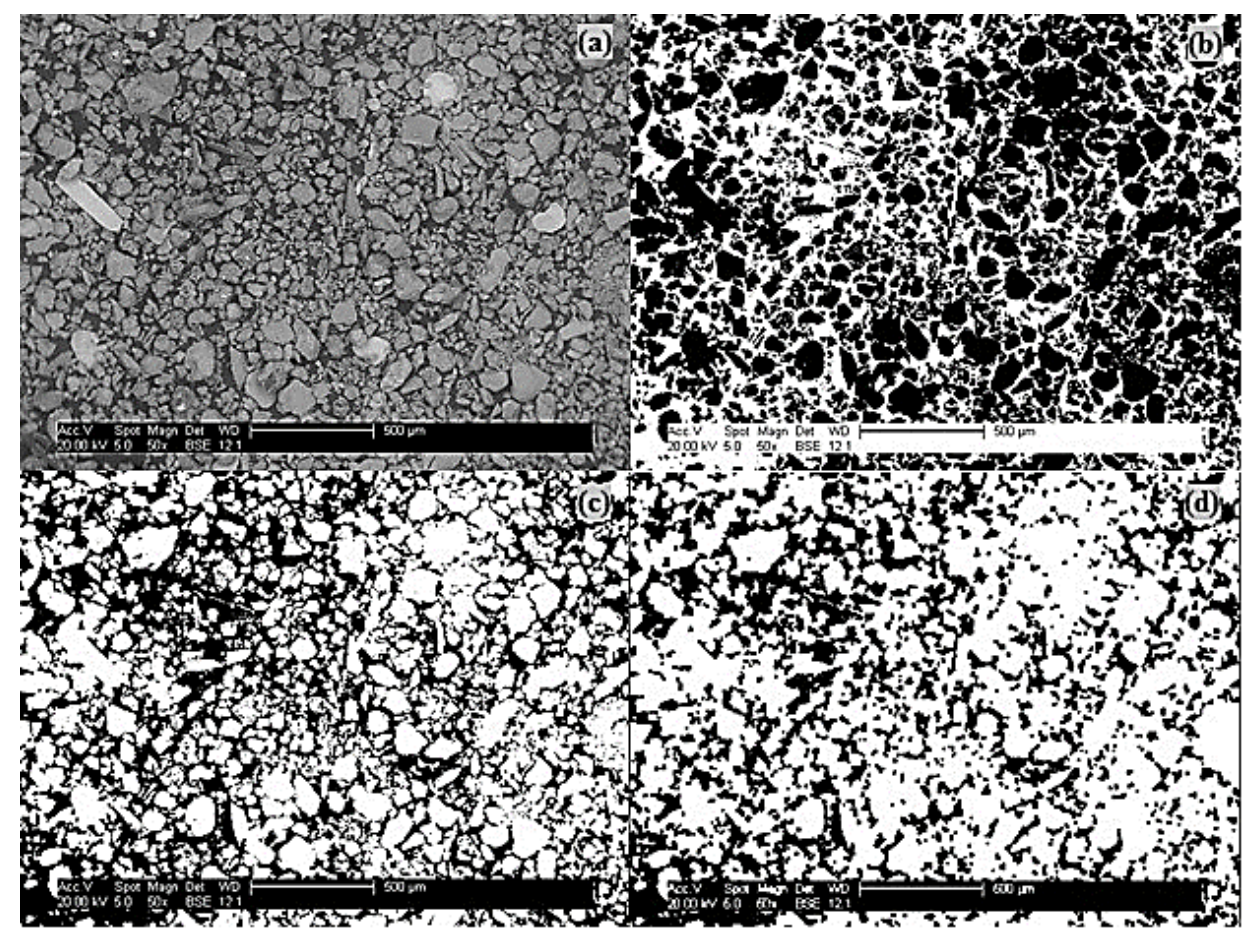

Figure 3: Annotated SEM microphotographs under ImageJ software analysis of (a) cleaved surface showing grain morphology, packing and cementation of a posttreatment sample, (b) grain morphology after thresholding of a post-treatment sample, (c) image after further thresholding, and (d) an example of image after thresholding and opening of binaries.

Image processing was conducted using ImageJ software (V. 1.50i). All images are scaled based on the provided scale bars in each photograph, Figure 3. The image is then sharpened using the 'Sharpen' command. Further, the grains were segmented using the 'Threshold' command, then smoothed, and the isolated pixels were removed using the 'Binary (Open)' command. Finally, the grain size was analysed using the 'Analyse Particles' command. For each measurement, a total of 100 grains were sampled and analysed. Each measurement was 
repeated 4 times and the average quantities were reported in Feret diameter, D (mm), which is defined as the farthest distance in the boundaries of a grain. Further, for each set of measurements, the Feret diameters of samples were used to calculate the geometric mean, $d_{g}$ (mm), Equation 1:

$$
d_{g}=\sqrt[n]{\prod_{i=1}^{n}} D_{i}
$$

Equation 1

Where $n$ is the number of grains $(n=100)$. The calculated $d_{g}$ is presented in Figure 4. Grain sorting, $\sigma_{\mathrm{D}}$, was then calculated by obtaining the standard deviation of $\phi$, where $\phi$ is defined based on the Krumbein logarithmic transformation, Equation 2 (Krumbein, 1934):

$$
\phi=-\log _{2} \mathrm{D}
$$

Equation 2

The sample permeability, $\mathrm{k}$, was calculated based on a proposed method by Krumbein and Monk (Krumbein and Monk, 1943) and Beard and Weyl (Beard and Weyl, 1973), Equation 3:

$$
k=760 d_{g}{ }^{2} \exp \left(-1.31 \sigma_{D}\right)
$$

\section{Equation 3}

The calculated sample permeabilities are presented in Figure 5.

\section{Results and discussion}

Previous studies (Aminu et al., 2017; Gilfillan et al., 2009; Liu et al., 2012, 2011; Shogenov et al., 2015) report that the acidification of formation waters, due to the dissolution of $\mathrm{CO}_{2}$, leads to brine-rock interaction and triggers dissolution or precipitation of rock minerals and cementation of the rocks which hold the rock grains together. Consequently, it can alter the reservoir rock grain-size characteristics and result in changing the permeability. In addition, the presence of impurities in the $\mathrm{CO}_{2}$ stream, injected into the reservoir, and their reaction with 
the formation water can further produce either weak or strong acids which can possibly affect rock permeability.

Quantitative XRD (QXRD) analyses of the samples are presented in Table 2 and the corresponding change observed in the reacted brine (ICP-MS and IC) are presented in Table 3. The non-reacted sample (S-NR) was characterised as a closely-packed granular sandstone structure which primarily comprised feldspar group minerals (k-feldspar and albite) and mainly quartz as the dominant mineral phases, and clay (mica), iron oxide (hematite), halite, ankerite, and analcime as accessory minerals. Moreover, the inter-grain cementation material is composed of calcite and chlorite. 

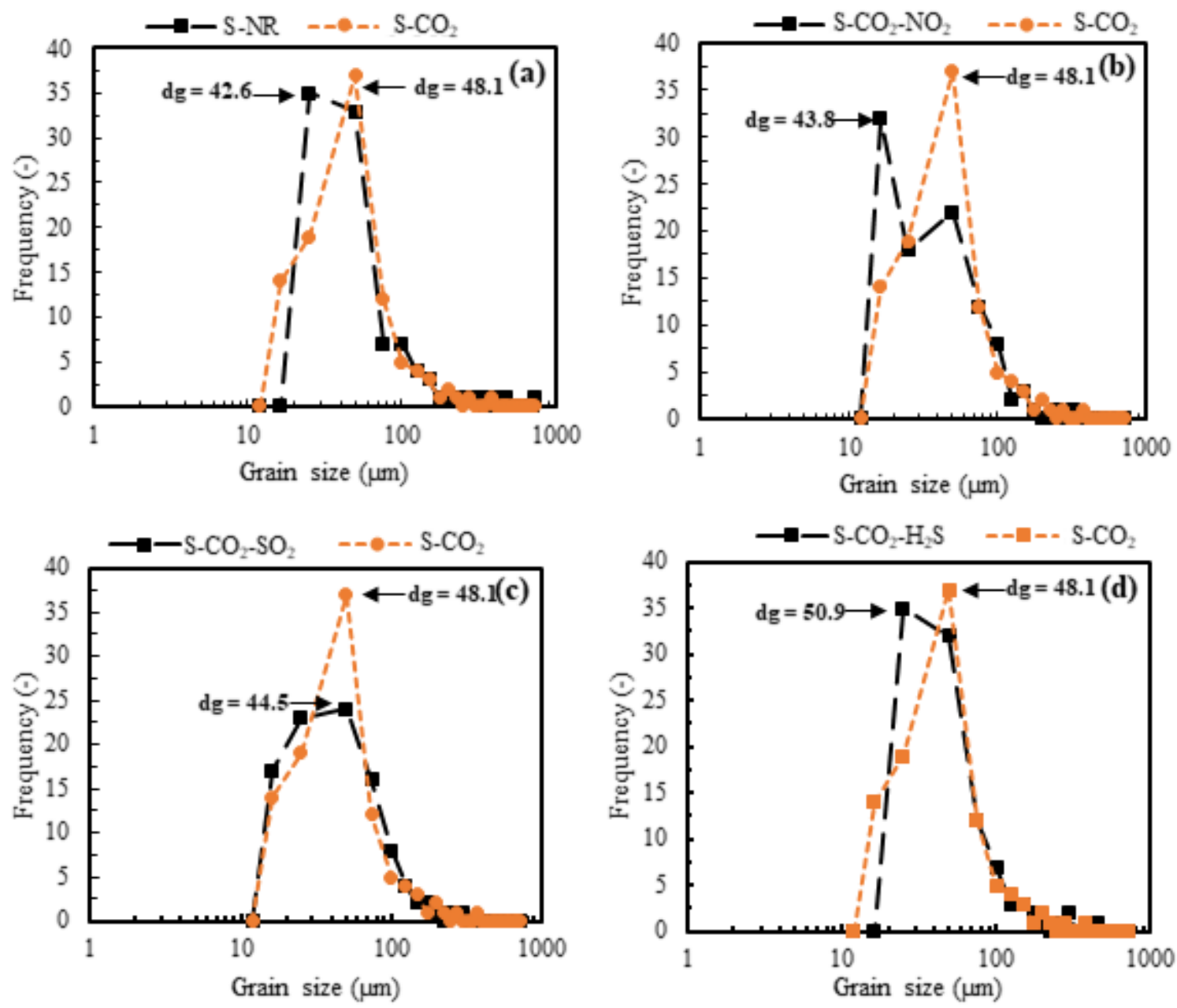

Figure 4: Logarithmic plots of changes in grain size distribution and for unreacted and reacted samples with pure and impure $\mathrm{CO}_{2}$, showing comparisons between (a) $\mathrm{S}$-NR and $\mathrm{S}-\mathrm{CO}_{2}$, (b) S-CO2-NO 2 and $\mathrm{S}-\mathrm{CO}_{2}$, (c) $\mathrm{S}-\mathrm{CO}_{2}-\mathrm{SO}_{2}$ and $\mathrm{S}-\mathrm{CO}_{2}$, and (d) $\mathrm{S}-\mathrm{CO}_{2}-\mathrm{H}_{2} \mathrm{~S}$ and $\mathrm{S}-\mathrm{CO}_{2}$. Note: $\mathrm{d}_{\mathrm{g}}$ is the geometric mean of the grain diameter. 
Table 2: QXRD analysis of mineral phases (wt.\%) for unreacted and reacted samples.

\begin{tabular}{|c|c|c|c|c|c|c|c|c|c|c|}
\hline Sample & Albite & Analcime & Ankerite & Calcite & Chlorite & Halite & Hematite & K-feldspar & Mica & Quartz \\
\hline S-NR & 18.1 & 3.3 & 17.8 & $<0.5$ & 0.8 & 1.1 & 0.5 & 7.8 & 7.9 & 42.6 \\
\hline $\mathrm{S}-\mathrm{CO}_{2}$ & 19.5 & 3.6 & 10.4 & - & 1.1 & - & 0.5 & 9.2 & 7.6 & 48.1 \\
\hline $\mathrm{S}-\mathrm{CO}_{2}-\mathrm{NO}_{2}$ & 18.7 & 3.7 & 15.8 & - & 1.3 & - & 0.6 & 8.8 & 7.3 & 43.8 \\
\hline $\mathrm{S}-\mathrm{CO}_{2}-\mathrm{SO}_{2}$ & 18.5 & 4.0 & 15.6 & $<0.5$ & 1.7 & - & 0.5 & 8.5 & 6.6 & 44.5 \\
\hline $\mathrm{S}-\mathrm{CO}_{2}-\mathrm{H}_{2} \mathrm{~S}$ & 20 & 3.5 & 8.9 & - & 1.1 & - & $<0.5$ & 9.1 & 6.3 & 50.9 \\
\hline
\end{tabular}


Table 3: Analyses of reacted brine.

\begin{tabular}{|c|c|c|c|c|c|c|c|c|c|c|c|c|c|c|}
\hline $\begin{array}{l}\text { Gas } \\
\text { Used }\end{array}$ & $\begin{array}{l}\text { Brine } \\
\text { Composition }\end{array}$ & Ca & Mg & $\mathbf{K}$ & $\mathrm{HCO}_{3}{ }^{-}$ & $\mathrm{SO}_{4}{ }^{2-}$ & $\mathrm{NO}_{3}{ }^{-}$ & $\begin{array}{l}\text { Total } \\
\text { S }\end{array}$ & $\mathrm{SiO}_{2}$ & $\mathbf{B a}$ & $\mathrm{Sr}$ & Mn & $\begin{array}{l}\text { Total } \\
\mathrm{Fe}\end{array}$ & $\mathrm{Fe}^{2+}$ \\
\hline & & $\mathrm{mg} / \mathrm{l}$ & $\mathrm{mg} / \mathrm{l}$ & $\mathrm{mg} / \mathrm{l}$ & $\mathrm{mg} / \mathrm{l}$ & $\mathrm{mg} / \mathrm{l}$ & $\mathrm{mg} / \mathrm{l}$ & $\mathrm{mg} / \mathrm{l}$ & $\mathrm{mg} / \mathrm{l}$ & $\mathrm{mg} / \mathrm{l}$ & $\mathrm{mg} / \mathrm{l}$ & $\mathrm{mg} / \mathrm{l}$ & $\mathrm{mg} / \mathrm{l}$ & $\mathrm{mg} / \mathrm{l}$ \\
\hline \multirow[t]{2}{*}{$\mathrm{CO}_{2}$} & Initial & $<10$ & $<0.60$ & 1.30 & 0.00 & $<40$ & $<24$ & 25.0 & $<0.34$ & $<0.01$ & 17.8 & 0.02 & 0.03 & $<0.005$ \\
\hline & Final & 247 & 264 & 8.10 & 2036 & $<40$ & $<24$ & $<16$ & 33.4 & 1.77 & 15.1 & 0.19 & 0.78 & $<0.005$ \\
\hline $\mathrm{CO}_{2}-\mathrm{NO}_{2}$ & Initial & $<10$ & $<0.60$ & 1.30 & 0.00 & $<40$ & $<24$ & 25.0 & $<0.34$ & $<0.01$ & 17.8 & 0.02 & 0.03 & $<0.005$ \\
\hline & Final & 453 & 317 & 13.9 & 1852 & 84.1 & 736 & 45.0 & 52.1 & 1.16 & 17.2 & 0.12 & 41.9 & 37.6 \\
\hline \multirow[t]{2}{*}{$\mathrm{CO}_{2}-\mathrm{SO}_{2}$} & Initial & $<10$ & $<0.60$ & 1.30 & 0.00 & $<40$ & $<24$ & 25.0 & $<0.34$ & $<0.01$ & 17.8 & 0.02 & 0.03 & $<0.005$ \\
\hline & Final & 694 & 368 & 12.9 & 2294 & 834 & $<24$ & 518 & 40.3 & 0.22 & 18.5 & 4.95 & 6.80 & 6.97 \\
\hline $\mathrm{CO}_{2}-\mathrm{H}_{2} \mathrm{~S}$ & Initial & $<10$ & $<0.60$ & 3.70 & 0.00 & $<40$ & $<24$ & 117 & $<0.34$ & 0.01 & $<0.0$ & $<0.01$ & 0.10 & 0.06 \\
\hline & Final & 515 & 265 & 2.80 & 2903 & $<40$ & $<24$ & 142 & 24.2 & 2.12 & 0.54 & 3.70 & 0.18 & 0.23 \\
\hline
\end{tabular}


After exposure to $\mathrm{CO}_{2}$ in the S-CO $\mathrm{CO}_{2}$ test, the largest changes in weight fractions were shown by quartz, which increased by about $11.4 \%$. Meanwhile the fraction of ankerite decreased substantially by about $41.6 \%$, while halite disappeared completely, which could be related to the initial salinity of the solution, and could also be further influenced by stirring during experiments as was discussed by Weisbrod et al. (Weisbrod et al., 2012). A notable observation is that the addition of $\mathrm{NO}_{2}$ and $\mathrm{SO}_{2}$ decreased the fraction of quartz. On the other hand, the presence of $\mathrm{H}_{2} \mathrm{~S}$ in the $\mathrm{CO}_{2}$ stream increased the fraction of quartz. The increase in quartz fraction is marginal given that $\mathrm{H}_{2} \mathrm{~S}$ is only slightly soluble in water to produce a weak acid, which immediately dissociates to produce other ions.

Depending on the impurities and $\mathrm{pH}$ of the formation water, quartz can react with carbonic acid, hydrogen ion or bicarbonates, which had already formed from the dissolution of $\mathrm{CO}_{2}$ in water, Equation 4 to Equation 8 (Rathnaweera et al., 2016; Shogenov et al., 2015).

$$
\begin{array}{cr}
\mathrm{CO}_{2}+\mathrm{H}_{2} \mathrm{O} \leftrightarrow \mathrm{H}_{2} \mathrm{CO}_{3} & \text { Equation } 4 \\
\mathrm{CO}_{2}+\mathrm{H}_{2} \mathrm{O} \leftrightarrow \mathrm{H}^{+}+\mathrm{HCO}_{3}{ }^{-} & \text {Equation 5 } \\
\mathrm{SiO}_{2}+2 \mathrm{H}_{2} \mathrm{CO}_{3} \leftrightarrow \mathrm{Si}+2 \mathrm{H}_{2} \mathrm{O}+2 \mathrm{CO}_{3} & \text { Equation 6 } \\
\mathrm{SiO}_{2}+4 \mathrm{H}^{+} \leftrightarrow \mathrm{Si}^{4+}+2 \mathrm{H}_{2} \mathrm{O} & \text { Equation 7 } \\
\mathrm{SiO}_{2}+4 \mathrm{HCO}_{3}{ }^{-} \leftrightarrow \mathrm{Si}+2 \mathrm{H}_{2} \mathrm{O}+4 \mathrm{CO}_{3} &
\end{array}
$$

In addition, the fraction of quartz can be possibly influenced by the reaction of k-feldspar and $\mathrm{CO}_{2}$ within the formation water, Equation 9 (Rosenqvist et al., 2014). 


$$
3 \mathrm{KAlSi}_{3} \mathrm{O}_{8}+2 \mathrm{CO}_{2}+2 \mathrm{H}_{2} \mathrm{O} \leftrightarrow \text { mica }+6 \mathrm{SiO}_{2}+2 \mathrm{~K}^{+}+2 \mathrm{HCO}_{3}^{-}
$$

However, the laboratory tests were relatively short compared to a real storage lifespan, and the quartz and feldspar dissolution may require extended time. Therefore, longer tests are required to further confirm the dissolution/precipitation behaviour of quartz and feldspar.

The effect of the $\mathrm{CO}_{2}$ stream impurities on the $\mathrm{pH}$ of brine over 9 months is given in Table 4 . The variation in permeability of rock samples after exposure to pure and impure $\mathrm{CO}_{2}$ streams is a function of the impurity type, the $\mathrm{pH}$ value of brine, and the stability of rock minerals. Depending on the type of impurity associated with the $\mathrm{CO}_{2}$ stream, the $\mathrm{pH}$ is altered due to the formation of strong or weak acids.

Table 4: The effect of $\mathrm{CO}_{2}$ stream impurities on the $\mathrm{pH}$ of brine over time.

\begin{tabular}{lllll}
\hline $\mathbf{p H}$ & $\mathrm{CO}_{2}$ & $\mathrm{CO}_{2}-\mathrm{NO}_{2}$ & $\mathbf{C O}_{2}-\mathrm{SO}_{2}$ & $\mathrm{CO}_{2}-\mathrm{H}_{2} \mathrm{~S}$ \\
\hline Initial & 7.65 & 7.65 & 7.65 & 7.65 \\
Final & 5.97 & 5.23 & 5.86 & 6.55 \\
\hline
\end{tabular}


The $\mathrm{pH}$ of the brine exposed to the $\mathrm{CO}_{2}$ stream, for the period of 9 months, was decreased from 7.65 to 5.97. In comparison with dissolution of the pure $\mathrm{CO}_{2}$ stream in the formation water that forms carbonic acid or bicarbonate (Steel et al., 2018), dissolution of $\mathrm{NO}_{2}$ impurity results in the production of a weak acid, $\mathrm{HNO}_{2}$, and a strong acid, $\mathrm{HNO}_{3}$, Equation 10 and Equation 11.

$$
\begin{array}{lr}
2 \mathrm{NO}_{2}+\mathrm{H}_{2} \mathrm{O} \leftrightarrow \mathrm{HNO}_{2}+\mathrm{HNO}_{3} & \text { Equation 10 } \\
3 \mathrm{NO}_{2}+\mathrm{H}_{2} \mathrm{O} \leftrightarrow 2 \mathrm{HNO}_{3}+\mathrm{NO} & \text { Equation 11 }
\end{array}
$$

Therefore, the addition of $\mathrm{NO}_{2}$ led to a reduction in $\mathrm{pH}$ from 5.97 to 5.23. The addition of $\mathrm{SO}_{2}$ led to a reduction in $\mathrm{pH}$ of the formation water from 5.97 to 5.86. The effect of $\mathrm{SO}_{2}$ in the $\mathrm{CO}_{2}$ stream can be explained according to Equation 12 to Equation 14:

$$
\begin{gathered}
\mathrm{SO}_{2}+\mathrm{H}_{2} \mathrm{O} \leftrightarrow \mathrm{H}_{2} \mathrm{SO}_{3} \\
\mathrm{SO}_{2}+\mathrm{H}_{2} \mathrm{O} \leftrightarrow \frac{3}{4} \mathrm{H}_{2} \mathrm{SO}_{4}+\frac{1}{4} \mathrm{H}_{2} \mathrm{~S} \\
\mathrm{SO}_{2}+\mathrm{H}_{2} \mathrm{O}+\frac{1}{2} \mathrm{O}_{2} \leftrightarrow \mathrm{H}_{2} \mathrm{SO}_{4}
\end{gathered}
$$

Equation 12

Equation 13

Equation 14

These reactions cause the formation of weak acids $\mathrm{H}_{2} \mathrm{SO}_{3}$ and $\mathrm{H}_{2} \mathrm{~S}$, and/or strong acid $\mathrm{H}_{2} \mathrm{SO}_{4}$ in the formation water. The reduction of the $\mathrm{pH}$ due to $\mathrm{CO}_{2}$ and $\mathrm{SO}_{2}$ mixtures in a sandstone saline aquifer during injectivity and storage has been confirmed by Waldmann et al. (Waldmann et al., 2016).

The addition of $\mathrm{H}_{2} \mathrm{~S}$ led to an increase in $\mathrm{pH}$ of the formation water from 5.97 to 6.55 , which can be explained according to the following reactions Equation 15 and Equation 16: 


$$
\begin{gathered}
\mathrm{H}_{2} \mathrm{~S}+\mathrm{H}_{2} \mathrm{O} \rightarrow \mathrm{HS}^{-}+\mathrm{H}_{3} \mathrm{O}^{+} \\
\mathrm{HS}^{-}+\mathrm{H}_{2} \mathrm{O} \rightarrow \mathrm{S}^{-}+\mathrm{H}_{3} \mathrm{O}^{+}
\end{gathered}
$$

Equation 16

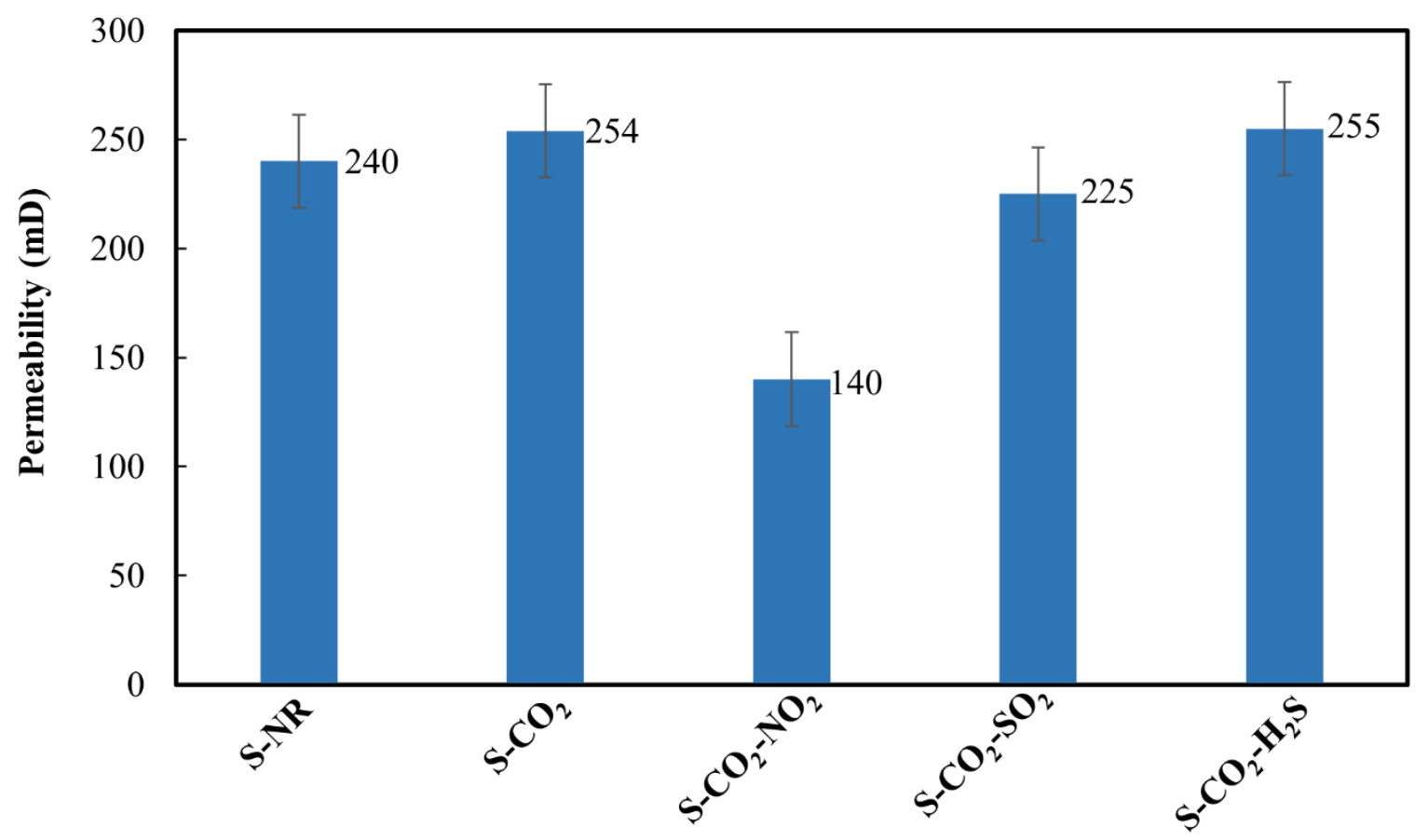

Figure 5: Permeability of unreacted samples and samples reacted with pure and impure $\mathrm{CO}_{2}$.

Figure 5 shows the effect of impurities on the permeability of rock samples over 9 months. The permeability of the sample exposed to the $\mathrm{CO}_{2}$ stream was increased from 240 to $254 \mathrm{mD}$. When compared with samples exposed to impure $\mathrm{CO}_{2}$, the introduction of $\mathrm{NO}_{2}$ and $\mathrm{SO}_{2}$ decreased permeability to 140 and $225 \mathrm{mD}$, respectively, while the effect of $\mathrm{H}_{2} \mathrm{~S}$ was negligible $(255 \mathrm{mD})$. A reduction in the permeability in the presence of $\mathrm{SO}_{2}(1 \% \mathrm{vol}$.$) is also reported by$ Waldmann et al. (Waldmann et al., 2016). They found that $\mathrm{SO}_{2}$ accelerates the dissolution of silica and precipitation of carbonates and sulphates, causing an alteration in the permeability of the samples. Wang et al. (Z. Wang et al., 2016) also observed that the dissolution of quartz 
was much faster in the presence of $\mathrm{SO}_{2}(2.5 \%$ vol. $)$, when $\mathrm{Si}$ is undersaturated in water. In addition, they found that the enhanced dissolution of quartz can cause precipitation of salt, which could also decrease the permeability of reservoir rocks.

As mentioned, the permeability of the rock sample is affected by dissolution/precipitation of both the cementing material and rock minerals such as calcite. The dissolution/precipitation of calcite involves three main simultaneous reactions, Equation 17 to Equation 19 (Plummer et al., 1978):

$$
\begin{gathered}
\mathrm{CaCO}_{3}+\mathrm{H}^{+} \leftrightarrow \mathrm{Ca}^{2+}+\mathrm{HCO}_{3}^{-} \\
\mathrm{CaCO}_{3}+\mathrm{H}_{2} \mathrm{CO}_{3} \leftrightarrow \mathrm{Ca}^{2+}+2 \mathrm{HCO}_{3}^{-} \\
\mathrm{CaCO}_{3}+\mathrm{H}_{2} \mathrm{O} \leftrightarrow \mathrm{Ca}^{2+}+\mathrm{HCO}_{3}{ }^{-}+\mathrm{OH}^{-}
\end{gathered}
$$

Equation 17

Equation 18

\section{Equation 19}

It is reported that the dissolution of even small amounts of cementing material (e.g., calcite) can considerably change the rock permeability by affecting the grain size distribution (LamyChappuis et al., 2013; Nogues et al., 2013; Sadhukhan et al., 2012; Yang et al., 2017). Figure 4 presents the effect of pure and impure $\mathrm{CO}_{2}$ on the grain size distribution of the rock samples. In comparison with the S-NR sample, exposure to the pure $\mathrm{CO}_{2}$ stream $\left(\mathrm{S}-\mathrm{CO}_{2}\right.$ test $)$ resulted in an increase in $d_{g}$ of the sample from 42.6 to $48.1 \mu \mathrm{m}$. The increase in $d_{g}$ can be associated with the decreased $\mathrm{pH}$ of the formation water in the $\mathrm{S}-\mathrm{CO}_{2}$ test. With regard to the $\mathrm{S}-\mathrm{CO}_{2}-\mathrm{NO}_{2}$ and S- $-\mathrm{CO}_{2}-\mathrm{SO}_{2}$ tests, the introduction of $\mathrm{NO}_{2}$ and $\mathrm{SO}_{2}$ into the $\mathrm{CO}_{2}$ stream resulted in a reduction in $\mathrm{d}_{\mathrm{g}}$ to 43.8 and $44.5 \mu \mathrm{m}$, respectively. However, in the $\mathrm{S}-\mathrm{CO}_{2}-\mathrm{H}_{2} \mathrm{~S}$ test, the addition of $\mathrm{H}_{2} \mathrm{~S}$ into the $\mathrm{CO}_{2}$ stream resulted in a slight increase in $\mathrm{d}_{\mathrm{g}}$ to $50.9 \mu \mathrm{m}$. The decrease in $\mathrm{d}_{\mathrm{g}}$ of rock samples exposed to impurities can be attributed to the lower $\mathrm{pH}$ of the formation water, compared to that with $\mathrm{S}-\mathrm{CO}_{2}$, which usually results in further dissolution of cementing material and quartz as the dominant mineral. However, it can be noted that switching from $\mathrm{S}-\mathrm{CO}_{2}-\mathrm{SO}_{2}$ 
to $\mathrm{S}-\mathrm{CO}_{2}-\mathrm{NO}_{2}$, for example, caused only a slight change in $\mathrm{d}_{\mathrm{g}}$ but there was a significant change in permeability. This phenomenon can be explained by production of strong acid due to dissolution of $\mathrm{CO}_{2}-\mathrm{NO}_{2}$ in the formation water, which enhances dissolution of inter-grain cementation, increasing permeability without necessarily causing a pronounced effect on grain size.

Finally, it should be noted that in addition to experiments, numerical simulations should be performed to determine the effects of $\mathrm{CO}_{2}$ and impurities, especially on storage capacity beyond the injection point, to understand overall injection efficiency. Previous studies (Gupta et al., 2001; Hall et al., 2016; Settari et al., 2001) required reservoir permeability values to solve problems of fluid flow in a variety of realistic settings, and the permeability values from this work can be used as inputs for cells in reservoir models, as well as for better understanding of risk associated with impure $\mathrm{CO}_{2}$ injection and migration in the reservoir.

\section{Conclusions}

In this work we studied, over a 9-month period, the changes in grain size parameters due to exposure to $\mathrm{CO}_{2}$ and impurities in simulated reservoir conditions using rock samples of the Bunter Sandstone formation to ascertain implications on physical reservoir quality using permeability variations as an indicator. The most significant changes in permeability were caused by $\mathrm{CO}_{2}-\mathrm{NO}_{2}$ brine-rock reactions which reduced sandstone permeability by $41.6 \%$. The results in this study revealed that the geometric mean of the grain diameter, and consequently, permeability of the rock samples reduced due to the effect of $\mathrm{CO}_{2}$ and impurities, which can be correlated with decreasing $\mathrm{pH}$ of the formation water. These results also suggest that it is necessary to evaluate the physical reservoir quality of potential storage formations depending on the nature of impurities present in the $\mathrm{CO}_{2}$ stream. The obtained data can, therefore, reduce 
the uncertainties about $\mathrm{CO}_{2}$ storage capacity with impurities in the $\mathrm{CO}_{2}$ stream and can be used to model the operation and performance of $\mathrm{CO}_{2}$ storage in saline aquifers.

\section{REFERENCES}

Adler, P.M., Jacquin, C.G., Quiblier, J.A., 1990. Flow in simulated porous media. Int. J. Multiph. Flow 16, 691-712. https://doi.org/10.1016/0301-9322(90)90025-E

Aminu, M.D., Nabavi, S.A., Rochelle, C.A., Manovic, V., 2017. A review of developments in carbon dioxide storage. Appl. Energy 208C, 1389-1419. https://doi.org/https://doi.org/10.1016/j.apenergy.2017.09.015

Bateman, K., Selby, L., Rushton, J., Wagner, D., 2015. ULTimateCO2: Understanding the Long-Term fate of geologically stored CO2. BGS, Nottingham, UK.

Bear, J., 1988. Dynamics of Fluids in Porous Media. Elsevier, New York.

Beard, D.C., Weyl, P.K., 1973. Influence of texture on porosity and permeability of unconsolidated sand. Am. Assoc. Pet. Geol. Bull. 57, 349-369.

Bifani, R., 1986a. Esmond Gas Complex. Geol. Soc. Spec. Publ. 23, 209-221. https://doi.org/10.1144/GSL.SP.1986.023.01.13

Bifani, R., 1986b. Esmond Gas Complex., Habitat of Palaeozoic gas in N.W. Europe. Proc. conference, London, 1985.

Blunt, M.J., Bijeljic, B., Dong, H., Gharbi, O., Iglauer, S., Mostaghimi, P., Paluszny, A., Pentland, C., 2013. Pore-scale imaging and modelling. Adv. Water Resour. 51, 197-216. https://doi.org/10.1016/j.advwatres.2012.03.003

Bolourinejad, P., Herber, R., 2014. Experimental and Modelling Study of Storage of CO2 and 
Impurities in a Depleted Gas Field in Northeast Netherlands. Energy Procedia 63, 28112820. https://doi.org/https://doi.org/10.1016/j.egypro.2014.11.303

Bond, C.E., Wightman, R., Ringrose, P.S., 2013. The influence of fracture anisotropy on CO2 flow. Geophys. Res. Lett. 40, 1284-1289. https://doi.org/10.1002/grl.50313

Bouquet, S., Bruel, D., De Fouquet, C., 2013. Influence of heterogeneities and upscaling on $\mathrm{CO} 2$ storage prediction at large scale in deep saline aquifer, in: Energy Procedia. pp. 4445-4456. https://doi.org/10.1016/j.egypro.2013.06.349

Coelho, R., Barrufet, M., Hascakir, B., 2015. Effect of impurities in carbon dioxide stream on phase behavior for geological storage of carbon dioxide in low API Gravity Oil Reservoirs, in: Carbon Management Technology Conference 2015: Sustainable and Economical CCUS Options, CMTC 2015. pp. 967-974.

Cooke-Yarborough, P., Smith, E., 2003. The Hewett Fields: Blocks 48/28a, 48/29, 48/30, 52/4a, 52/5a, UK North Sea: Hewett, Deborah, Big Dotty, Little Dotty, Della, Dawn and Delilah Fields. Geol. Soc. Mem. 20, 731-739. https://doi.org/10.1144/GSL.MEM.2003.020.01.60

Coskun, S.B., Wardlaw, N.C., 1993. Estimation of permeability from image analysis of reservoir sandstones. J. Pet. Sci. Eng. 10, 1-16. https://doi.org/https://doi.org/10.1016/0920-4105(93)90046-H

Dance, T., 2013. Assessment and geological characterisation of the CO2CRC Otway Project $\mathrm{CO} 2$ storage demonstration site: From prefeasibility to injection. Mar. Pet. Geol. 46, 251-269. https://doi.org/https://doi.org/10.1016/j.marpetgeo.2013.06.008

Gilfillan, S.M. V, Lollar, B.S., Holland, G., Blagburn, D., Stevens, S., Schoell, M., Cassidy, 
M., Ding, Z., Zhou, Z., Lacrampe-Couloume, G., Ballentine, C.J., 2009. Solubility trapping in formation water as dominant CO2 sink in natural gas fields. Nature 458, 614-618. https://doi.org/10.1038/nature07852

Gunter, W.D., Perkins, E.H., McCann, T.J., 1993. Aquifer disposal of CO2-rich gases: Reaction design for added capacity. Energy Convers. Manag. 34, 941-948. https://doi.org/10.1016/0196-8904(93)90040-H

Gupta, A., Penuela, G., Avila, R., 2001. An integrated approach to the determination of permeability tensors for naturally fractured reservoirs. J. Can. Pet. Technol. 40, 43-48.

Hall, M.R., Rigby, S.P., Dim, P., Bateman, K., Mackintosh, S.J., Rochelle, C.A., 2016. Post$\mathrm{CO} 2$ injection alteration of the pore network and intrinsic permeability tensor for a Permo-Triassic sandstone. Geofluids 16, 249-263. https://doi.org/10.1111/gfl.12146

Heinemann, N.., Wilkinson, M.., Pickup, G.E.., Haszeldine, R.S.., Cutler, N.A.. c, 2012. CO2 storage in the offshore UK Bunter Sandstone Formation. Int. J. Greenh. Gas Control 6, 210-219. https://doi.org/10.1016/j.ijggc.2011.11.002

Holloway, S., Vincent, C.J., Bentham, M.S., Kirk, K.L., 2006. Top-down and bottom-up estimates of $\mathrm{CO} 2$ storage capacity in the United Kingdom sector of the southern North Sea basin. Environ. Geosci. 13, 71-84. https://doi.org/10.1306/eg.11080505015

Hussain, F., Michael, K., Cinar, Y., 2016. A numerical study of the effect of brine displaced from $\mathrm{CO} 2$ storage in a saline formation on groundwater. Greenh. Gases Sci. Technol. 6, 94-111. https://doi.org/10.1002/ghg.1539

IPCC, 2005. Special Report on Carbon Dioxide Capture and Storage, Cambridge University Press. Cambridge. https://doi.org/10.1021/cr2003272 
Jafari Raad, S.M., Hassanzadeh, H., 2016. Does impure CO2 impede or accelerate the onset of convective mixing in geological storage? Int. J. Greenh. Gas Control 54, 250-257. https://doi.org/10.1016/j.ijggc.2016.09.011

Jenkins, C.R., Cook, P.J., Ennis-King, J., Undershultz, J., Boreham, C., Dance, T., De Caritat, P., Etheridge, D.M., Freifeld, B.M., Hortle, A., Kirste, D., Paterson, L., Pevzner, R., Schacht, U., Sharma, S., Stalker, L., Urosevic, M., 2012. Safe storage and effective monitoring of CO2in depleted gas fields. Proc. Natl. Acad. Sci. U. S. A. 109, E35-E41. https://doi.org/10.1073/pnas.1107255108

Kaldi, JG Gibson-Poole, CM Payenberg, T., 2009. Geological input to selection and evaluation of CO2 geosequestration sites, in: Carbon Dioxide Sequestration in Geological Media--State of the Science: AAPG Studies in Geology 59. pp. 5-16.

Ketter, F.J., 1991. The Esmond, Forbes and Gordon Fields, Blocks 43/8a, 43/13a, 43/15a, 43/20a, UK North Sea. Geol. Soc. Mem. 14, 425-432. https://doi.org/10.1144/GSL.MEM.1991.014.01.53

Krumbein, W., 1934. Size frequency distribution of sediments. J. Sediment. Res. 4, 65-77.

Krumbein, W., Monk, G., 1943. Permeability as a function of the size parameters of unconsolidated sand. Trans. AIME 151, 153-163.

Lamy-Chappuis, B., Yardley, B., Grattoni, C., 2013. The effect of CO2-fluid-rock interactions on the porosity and permeability of calcite-bearing sandstone. Am. Geophys. Union, Fall Meet. 2013.

Lei, H., Li, J., Li, X., Jiang, Z., 2016. EOS7Cm: An improved TOUGH2 module for simulating non-isothermal multiphase and multicomponent flow in $\mathrm{CO} 2-\mathrm{H} 2 \mathrm{~S}-\mathrm{CH} 4-$ 
brine systems with high pressure, temperature and salinity. Comput. Geosci. 94, 150161. https://doi.org/10.1016/j.cageo.2016.06.011

Li, D., Jiang, X., 2014. A numerical study of the impurity effects of nitrogen and sulfur dioxide on the solubility trapping of carbon dioxide geological storage. Appl. Energy 128, 60-74. https://doi.org/https://doi.org/10.1016/j.apenergy.2014.04.051

Liu, F., Lu, P., Griffith, C., Hedges, S.W., Soong, Y., Hellevang, H., Zhu, C., 2012. CO2brine-caprock interaction: Reactivity experiments on Eau Claire shale and a review of relevant literature. Int. J. Greenh. Gas Control 7, 153-167. https://doi.org/https://doi.org/10.1016/j.ijggc.2012.01.012

Liu, F., Lu, P., Zhu, C., Xiao, Y., 2011. Coupled reactive flow and transport modeling of CO2 sequestration in the Mt. Simon sandstone formation, Midwest U.S.A. Int. J. Greenh. Gas Control 5, 294-307. https://doi.org/10.1016/j.ijggc.2010.08.008

Masch, F.D., Denny, K.J., 1966. Grain size distribution and its effect on the permeability of unconsolidated sands. Water Resour. Res. 2, 665-677. https://doi.org/10.1029/WR002i004p00665

Mostaghimi, P., Blunt, M.J., Bijeljic, B., 2013. Computations of Absolute Permeability on Micro-CT Images. Math. Geosci. 45, 103-125. https://doi.org/10.1007/s11004-0129431-4

NOAA National Centers for Environmental Information, 2017. State of the Climate: Global Climate Report for March 2017, published online April 2017, retrieved on September 24, 2017 from https://www.ncdc.noaa.gov/sotc/global/201703. [WWW Document].

Nogues, J.P., Fitts, J.P., Celia, M.A., Peters, C.A., 2013. Permeability evolution due to 
dissolution and precipitation of carbonates using reactive transport modeling in pore networks. Water Resour. Res. 49, 6006-6021. https://doi.org/10.1002/wrcr.20486

Noy, D.J., Holloway, S., Chadwick, R.A., Williams, J.D.O., Hannis, S.A., Lahann, R.W., 2012. Modelling large-scale carbon dioxide injection into the Bunter Sandstone in the UK Southern North Sea. Int. J. Greenh. Gas Control 9, 220-233. https://doi.org/10.1016/j.ijggc.2012.03.011

Okabe, H., Blunt, M.J., 2004. Prediction of permeability for porous media reconstructed using multiple-point statistics. Phys. Rev. E - Stat. Nonlinear, Soft Matter Phys. 70, 066135/1-066135/10. https://doi.org/10.1103/PhysRevE.70.066135

Øren, P.-E., Bakke, S., Arntzen, O.J., 1998. Extending Predictive Capabilities to Network Models. SPE J. 3, 324-335.

Pearce, J.K., Dawson, G.K.W., Law, A.C.K., Biddle, D., Golding, S.D., 2016a. Reactivity of micas and cap-rock in wet supercritical $\mathrm{CO} 2$ with $\mathrm{SO} 2$ and $\mathrm{O} 2$ at $\mathrm{CO} 2$ storage conditions. Appl. Geochemistry 72, 59-76. https://doi.org/10.1016/j.apgeochem.2016.06.010

Pearce, J.K., Golab, A., Dawson, G.K.W., Knuefing, L., Goodwin, C., Golding, S.D., 2016b. Mineralogical controls on porosity and water chemistry during $\mathrm{O} 2-\mathrm{SO} 2-\mathrm{CO} 2$ reaction of CO2 storage reservoir and cap-rock core. Appl. Geochemistry 75, 152-168. https://doi.org/10.1016/j.apgeochem.2016.11.002

Pearce, J.K., Kirste, D.M., Dawson, G.K.W., Farquhar, S.M., Biddle, D., Golding, S.D., Rudolph, V., 2015a. SO2 impurity impacts on experimental and simulated CO2-waterreservoir rock reactions at carbon storage conditions. Chem. Geol. 399, 65-86. 
https://doi.org/10.1016/j.chemgeo.2014.10.028

Pearce, J.K., Law, A.C.K., Dawson, G.K.W., Golding, S.D., 2015b. SO2-CO2 and pure CO2 reactivity of ferroan carbonates at carbon storage conditions. Chem. Geol. 411, 112-124. https://doi.org/10.1016/j.chemgeo.2015.07.001

Perrin, J.-C., Benson, S., 2010. An experimental study on the influence of sub-core scale heterogeneities on CO2 distribution in reservoir rocks. Transp. Porous Media 82, 93109. https://doi.org/10.1007/s11242-009-9426-x

Plummer, L.N., Wigley, T.M.L., Parkhurst, D.L., 1978. Kinetics of calcite dissolution in CO2-water systems at 5 degree to 60 degree C and 0.0 to 1.0 atm. CO2. Am J Sci 278, $179-216$.

Pruess, K., 2005. ECO2N: A TOUGH2 fluid property module for mixtures of water, $\mathrm{NaCl}$, and CO2. Lawrence Berkeley Natl. Lab. Rep. LBNL-57952.

Ranjith, P.G., Perera, M.S.A., Khan, E., 2013. A study of safe CO2 storage capacity in saline aquifers: A numerical study. Int. J. Energy Res. 37, 189-199. https://doi.org/10.1002/er.2954

Rathnaweera, T.D., Ranjith, P.G., Perera, M.S.A., 2016. Experimental investigation of geochemical and mineralogical effects of $\mathrm{CO} 2$ sequestration on flow characteristics of reservoir rock in deep saline aquifers. Sci. Rep. 6. https://doi.org/10.1038/srep19362

Riebeek, H., 2011. Global Warming [WWW Document]. Earth Obs. NASA. URL https://earthobservatory.nasa.gov/Features/GlobalWarming/page2.php (accessed 6.28.17).

Rietveld, H.M., 1969. A profile refinement method for nuclear and magnetic structures. J. 
Appl. Crystallogr. 2, 65-71. https://doi.org/doi: 10.1107/S0021889869006558

Ritchie, J.S., Pratsides, P., 1993. The Caister Fields, Block 44/23a, UK North Sea. Pet. Geol. Conf. Proc. 4, 759-769. https://doi.org/10.1144/0040759

Roberts, A.P., 1997. Statistical reconstruction of three-dimensional porous media from twodimensional images. Phys. Rev. E - Stat. Physics, Plasmas, Fluids, Relat. Interdiscip. Top. 56, 3203-3212.

Rosenqvist, J., Kilpatrick, A.., Yardley, B.W.D., Rochelle, C.A., 2014. Dissolution of Kfeldspar at CO2-saturated conditions. Geophys. Res. Abstr. 16.

Sadhukhan, S., Gouze, P., Dutta, T., 2012. Porosity and permeability changes in sedimentary rocks induced by injection of reactive fluid: A simulation model. J. Hydrol. 450-451, 134-139. https://doi.org/10.1016/j.jhydrol.2012.05.024

Settari, A., Walters, D.A., Behie, G.A., 2001. Use of coupled reservoir and geomechanical modelling for integrated reservoir analysis and management. J. Can. Pet. Technol. 40, $55-61$.

Shepherd, R.G., 1989. Correlations of Permeability and Grain Size. Groundwater 27, 633638. https://doi.org/10.1111/j.1745-6584.1989.tb00476.x

Shogenov, K., Shogenova, A., Vizika-Kavvadias, O., Nauroy, J.-F., 2015. Experimental modeling of CO2-fluid-rock interaction: The evolution of the composition and properties of host rocks in the Baltic Region. Earth Sp. Sci. 2, 262-284. https://doi.org/10.1002/2015EA000105

Shukla, R., Ranjith, P., Haque, A., Choi, X., 2010. A review of studies on CO2 sequestration and caprock integrity. Fuel 89, 2651-2664. 
https://doi.org/https://doi.org/10.1016/j.fuel.2010.05.012

Soong, Y., Howard, B.H., Dilmore, R.M., Haljasmaa, I., Crandall, D.M., Zhang, L., Zhang, W., Lin, R., Irdi, G.A., Romanov, V.N., Mclendon, T.R., 2016. CO2/brine/rock interactions in Lower Tuscaloosa formation. Greenh. Gases Sci. Technol. 6, 824-837. https://doi.org/10.1002/ghg.1611

Steel, L., Mackay, E., Maroto-Valer, M.M., 2018. Experimental investigation of CO2-brinecalcite interactions under reservoir conditions. Fuel Process. Technol. 169, 122-131. https://doi.org/https://doi.org/10.1016/j.fuproc.2017.09.028

Talman, S., 2015. Subsurface geochemical fate and effects of impurities contained in a CO2 stream injected into a deep saline aquifer: What is known. Int. J. Greenh. Gas Control 40, 267-291. https://doi.org/10.1016/j.ijggc.2015.04.019

Taylor, J.C., 1991. Computer Programs for Standardless Quantitative Analysis of Minerals Using the Full Powder Diffraction Profile. Powder Diffr. 6, 2-9. https://doi.org/10.1017/S0885715600016778

Thovert, J.F., Salles, J., Adler, P.M., 1993. Computerized characterization of the geometry of real porous media: Their discretization, analysis and interpretation. J. Microsc. 170, 6579. https://doi.org/10.1111/j.1365-2818.1993.tb03324.x

Torp, T.A., Gale, J., 2004. Demonstrating storage of CO2 in geological reservoirs: The Sleipner and SACS projects. Energy 29, 1361-1369. https://doi.org/https://doi.org/10.1016/j.energy.2004.03.104

Underhill, J.R., 2009. Role of intrusion-induced salt mobility in controlling the formation of the enigmatic "Silverpit Crater", UK Southern North Sea. Pet. Geosci. 15, 197-216. 
https://doi.org/10.1144/1354-079309-843

Verdon, J.P., 2012. Microseismic Monitoring and Geomechanical Modelling of CO2 Storage in Subsurface Reservoirs. PhD thesis, University of Bristol.

Waldmann, S., Hofstee, C., Koenen, M., Loeve, D., Liebscher, A., Neele, F., 2016.

Physicochemical effects of discrete $\mathrm{CO} 2-\mathrm{SO} 2$ mixtures on injection and storage in a sandstone aquifer. Int. J. Greenh. Gas Control 54, 640-651.

https://doi.org/10.1016/j.ijggc.2016.07.026

Waldmann, S., Rütters, H., 2016. Geochemical effects of SO2 during CO2 storage in deep saline reservoir sandstones of Permian age (Rotliegend) - A modeling approach. Int. J. Greenh. Gas Control 46, 116-135. https://doi.org/10.1016/j.ijggc.2016.01.005

Wang, J., Wang, Z., Ryan, D., Lan, C., 2015. A study of the effect of impurities on CO2 storage capacity in geological formations. Int. J. Greenh. Gas Control 42, 132-137. https://doi.org/10.1016/j.ijggc.2015.08.002

Wang, K., Xu, T., Wang, F., Tian, H., 2016. Experimental study of CO2-brine-rock interaction during CO2 sequestration in deep coal seams. Int. J. Coal Geol. 154-155, 265-274. https://doi.org/https://doi.org/10.1016/j.coal.2016.01.010

Wang, Z., Wang, J., Lan, C., He, I., Ko, V., Ryan, D., Wigston, A., 2016. A study on the impact of $\mathrm{SO} 2$ on $\mathrm{CO} 2$ injectivity for $\mathrm{CO} 2$ storage in a Canadian saline aquifer. Appl. Energy 184, 329-336. https://doi.org/https://doi.org/10.1016/j.apenergy.2016.09.067

Warren, E.A., Smalley, P.C., 1994. North Sea formation waters atlas, Oceanographic Literature Review.

Weibel, R., Kjøller, C., Bateman, K., Laier, T., Nielsen, L.H., Purser, G., 2014. Carbonate 
dissolution in Mesozoic sand- and claystones as a response to $\mathrm{CO} 2$ exposure at $70^{\circ} \mathrm{C}$ and 20MPa. Appl. Geochemistry 42, 1-15.

https://doi.org/10.1016/j.apgeochem.2013.12.006

Weisbrod, N., Alon-Mordish, C., Konen, E., Yechieli, Y., 2012. Dynamic dissolution of halite rock during flow of diluted saline solutions. Geophys. Res. Lett. 39. https://doi.org/10.1029/2012GL051306

Williams, J.D.O., Bentham, M., Jin, M., Pickup, G., Mackay, E., Gammer, D., Green, A., 2013a. The Effect of Geological Structure and Heterogeneity on CO2 Storage in Simple 4-way Dip Structures; a Modeling Study from the UK Southern North Sea. Energy Procedia 37, 3980-3988. https://doi.org/https://doi.org/10.1016/j.egypro.2013.06.297

Williams, J.D.O., Holloway, S., 2012. The capability of faults and top seals in the Bunter Sandstone of the UK Southern North Sea to seal carbon dioxide, in: Fault and Top Seals: From Characterization to Modelling.

Williams, J.D.O., Holloway, S., Williams, G.A., 2014. Pressure constraints on the CO2 storage capacity of the saline water-bearing parts of the Bunter Sandstone Formation in the UK Southern North Sea. Pet. Geosci. 20, 155-167. https://doi.org/10.1144/petgeo2013-019

Williams, J.D.O., Jin, M., Bentham, M., Pickup, G.E., Hannis, S.D., Mackay, E.J., 2013b. Modelling carbon dioxide storage within closed structures in the UK Bunter Sandstone Formation. Int. J. Greenh. Gas Control 18, 38-50. https://doi.org/10.1016/j.ijggc.2013.06.015

Wolf, J.L., Niemi, A., Bensabat, J., Rebscher, D., 2016. Benefits and restrictions of 2D 
reactive transport simulations of $\mathrm{CO} 2$ and $\mathrm{SO} 2$ co-injection into a saline aquifer using TOUGHREACT V3.0-OMP. Int. J. Greenh. Gas Control 54, 610-626. https://doi.org/10.1016/j.ijggc.2016.07.005

Wollenweber, J., Alles, S. a., Kronimus, A., Busch, A., Stanjek, H., Krooss, B.M., 2009. Caprock and overburden processes in geological CO2 storage: An experimental study on sealing efficiency and mineral alterations, in: Energy Procedia. pp. 3469-3476. https://doi.org/10.1016/j.egypro.2009.02.138

Yang, G., Li, Y., Atrens, A., Yu, Y., Wang, Y., 2017. Numerical Investigation into the Impact of CO2-Water-Rock Interactions on CO2 Injectivity at the Shenhua CCS Demonstration Project, China. Geofluids Volume 201, 17. https://doi.org/https://doi.org/10.1155/2017/4278621

Ziabakhsh-Ganji, Z., Kooi, H., 2014. Sensitivity of the CO2 storage capacity of underground geological structures to the presence of SO2 and other impurities. Appl. Energy 135, 4352. https://doi.org/10.1016/j.apenergy.2014.08.073 